\title{
Scenario of the Foreign Direct Investment (FDI) in Bangladesh: An Evaluation
}

\author{
Dr. Alak Kumar Saha \\ Associate Professor Department of Accounting Barguna Govt. College, Barguna Bangladesh
}

\begin{abstract}
The Economic indicators which are also considered to be the mirrors of economic scenario show the real picture of the development of a country like Bangladesh. Accordingly, Foreign Direct Investment (FDI) can be termed in this regard and it can represent Bangladesh as one of the developing indicators in terms of development structure. The objective of the study is to focus the position of FDI in Bangladesh along with its problems and remedies. The study in fact, finds that the contribution FDI of developed and developing countries in Bangladesh is not so appreciating because of some uncertainties like uneven ratio in between savings and investments, unsound GDP, trade deficit, political instability and so on. To develop the scenario of FDI in Bangladesh some suggestions have been outlined in this study.
\end{abstract}

Key Words: FDI, GDP, Global Perspective, Investment \& Savings, Trade Deficit.

\section{Introduction}

To smoothly run the wheel of economy of a developing country like Bangladesh Foreign Direct Investment (FDI) is considered to be one of the important determinants which can help enhance the economic growth. Basically, the home countries show interest to invest in the host countries on the basis of certainties to be prevailing there. In fact, Foreign Aid and Foreign Direct Investment are introduced for the betterment of a country, while the former is used in terms of grants and loan; and the later helps a country (host country) to implement a project or projects where the home country's investor has a share for interest/profit on host country. Foreign Aid is received but its productivity cannot be measured directly so far, while FDI ensures the capital to be invested by the foreigners (home countries) separately or along with the local investors (host countries). It (FDI) strengthens the capital investment towards the economy of a country. Basically, FDI is used to remove the gap between the saving and investment. For example, internal Saving-GDP ratio was 20.30 percent in 2006 and the Investment-GDP ratio was 24.7 percent in the same financial year, these were 20.50 percent and 24.30 percent respectively in 2007 indicating the reduction of the gap by 0.6 percent (4.4-3.8 percents) which was the result of the impact of FDI so far. ${ }^{1}$ The idea about FDI has come to Bangladesh in the decade of 1980 so far and since then it has expanded its area by its own nature. But in the developing country like Bangladesh, FDI cannot play a lot of role in the increase of GDP growth through the implication of industrial sector, while industrial sector is contributing to the GDP in Bangladesh by around 30 percent. $^{2}$ Why the FDI is not enriched in Bangladesh, needs to be revealed through the analyses concerned. With a view to highlighting the scenario of FDI in Bangladesh, the study is planned.

\section{Objectives of the Study}

The main objective of the study is to learn about FDI in Bangladesh, while other objectives are:

1. To show the position of FDI in Bangladesh;

2. To find out the problems associated with the FDI in Bangladesh and

3. To suggest for creating congenial atmosphere of FDI in Bangladesh.

\section{Review of the Literatures}

Khan Md. Azizur Rahman ${ }^{3}$ conducted a study on "Globalization and the Climate of Foreign Direct Investment: A Case for Bangladesh" where he opined that Foreign Direct Investment is dramatically increasing in this age of globalization. It has played important role for economic growth in this global process. But, the distribution of FDI is uneven in all over the world. Some countries are ahead and some are lagged behind to attract foreign direct investment. The objectives of the study were to describe the overall background, trends and definition of FDI in recent years; to reveal the theoretical development and extensive literature review to find out the appropriate variables to deter the Foreign Direct Investment from different reputed studies and to focus on the challenges, opportunities, investment and economic environment associated with the inflow of FDI in Bangladesh. The study finds the determining factors of FDI in Bangladesh as market size and access, trade and investment, infrastructure, foreign aid, human resources, inflation etc. It ends up with the conclusion to promote the inflow of foreign direct investment with a view to taking measures to strengthen the positive impacts and reduce the negative impacts of FDI in Bangladesh. 
Anu Mohammad ${ }^{4}$ in his research paper titled "Foreign Direct Investment and Utilization of Natural Gas in Bangladesh: A note on understanding the trap in Development Disguise' highlighted that Foreign Aid (FA) and Foreign Direct Investment (FDI) have always been considered as crucial in development of a country especially in the underdeveloped countries. It has always been argued in modernization theories, later also by second generation modernization theorists that the capital inflow, in either form, would help third world countries to give a big push in the economy and would break the vicious cycle of poverty and underdevelopment. FDI, according to this dominant view, would contribute in economic development of the 'underdeveloped' countries in different ways. It would bring foreign currency along with latest technology, skill manpower, new ideas and modern management; it would also create conditions for strengthening and expanding productive base of the host economies. He focused on the practical experience in Bangladesh and opined that time has come to examine established hypothesis that FDI per sector can ensure or at least help the economy to develop and industrialize. In that article an attempt has been made to investigate the natural gas sector and to examine whether optimum utilization of natural gas is directly or inversely correlated to the present form of FDI. The objectives of the study were to understand the whole scenario, to explore the economics and power matrix behind the crisis where natural gas resources seem to have appeared as a liability for the people of Bangladesh

This article reveals that the whole foreign investment scenario in gas sector does not stand up to scrutiny. The findings of the study conclude that the FDI took place in gas sector was not warranted considering the local capability and demand-supply scenario. The article also examines the viability of exporting gas.

Another report ${ }^{5}$ titled "FDI in South Asia: Challenges and Prospects" published in Briefing Paper of South Asia Watch on Trade, Economics and Environment focused that FDI has been one of the hotly debated and sensitive issues in international economics. There is no dearth of people who could argue either in favor of or against FDI. There are many factors like economic and non-economic to be considered for having the comprehensive idea about the same. The objective of the paper is to highlight major issues related to FDI with reference to South Asian countries and other developing countries and to make some policy recommendations on the development of FDI. The paper finds and recommends that South Asia needs to work in a coordinated manner and devise a common investment policy if it is to succeed in attracting huge FDI inflow; The governments of the region should focus on institutional development so as to ensure transparency, accountability and predictability; Concentrating excessively on "carrots" might not benefit the developing countries in the long run. The possible negative consequence of FDI should also be taken into account while devising relevant policies and as initiated in the Non-aligned Movement (NAM) Meeting in Kuala Lumpur, avenues to explore ways to see how investors from South Asia can invest in other countries should be created.

\section{Methodology of the Study}

The study is mainly based on secondary information and data, while these have been collected from the various documents and papers like Annual Report of Bangladesh Bank, Monthly Economic Trends prepared by Statistics Department of Bangladesh Bank, Bangladesh Economic Review, Industrial Policy-2005, Annual Budgets, Reviewed Literatures, Web Site Data, selected Books, Journals and Daily News Papers covering mainly during the period of 2005-2010. Besides, some other years have been considered in relevant cases. Analyses of the study have been done through the tabular form, charts and diagrams on the basis of available data.

\section{Terms and Concepts}

The term, Foreign Direct Investment (FDI) can be defined as the investment which is directly invested in a particular country (host country) by the people of the other countries (home countries) in collaboration with the local investors or alone. According to the definition given by the World Trade Organization (WTO), "FDI occurs when an investor based in one country (the home country) acquires an asset in another country (the host country) with the intent to manage that asset. The management dimension is what distinguishes FDI from PortFolio Investment in foreign stocks, bonds and other financial instruments". ${ }^{6}$ Basically, the concept of FDI has been developed in the study in terms of a developing country like Bangladesh.

\section{Limitation of the Study}

The study has data limitation and time limitation. Had these been minimized, the study would have been effective more.

\section{Scenario of the FDI in Bangladesh}

Though FDI has a lot of potentialities in improving economic growth of a country, the question of optimum distribution of it remains behind the scene. In fact, the decision of the investors mainly depends upon their mental demand which is somehow existed with the organizational agreements like World Trade 
Organization, Association of South East Asian Nation, South Asian Free Trade Agreement, North African Free Trade Agreement, world economic environment, willingness of the developed countries, host countries economic condition, political situation, infra-structural condition and so on.

In the perspective of Bangladesh foreign investors from both the developed and developing countries come forward to invest their capital. For example, 27 countries from various regions of the world and the countries from East-Asian region proposed for FDI in Bangladesh while the amount was to be 94.90 percent of the total investment during 2006-07. Among the countries concerned UAE, USA, Singapore, South Korea, UK, India and China played crucial role of FDI in Bangladesh. The following facts concerned could reveal in detail (Vide Table 1).

The Table indicates that during the period 13 countries from Asian region registered with Bangladesh Board of Investment for Tk. 889930.80 millions which belonged to 88 projects while 30 projects of Tk. 42321.20 millions from 12 countries of European region, 12 projects concerning Tk. 5026.00 millions from USA and 3 projects for Tk. 469.80 millions from Canada were proposed.

Basically, the industrial sectors which have attracted the foreign investors to involve themselves with FDI in Bangladesh are gas, textile, leather, engineering, agriculture, chemical and service so far based upon which the earnings of the country existed can play crucial role in the economy along with the reduction of trade deficit. The trade deficit of Bangladesh mainly rises because of the imbalance of trade and payments, while the deficit is somehow recouped through the earnings of export, foreign aid and remittance of the expatriates. The attainment of FDI can reduce the deficit through the attractive ROI (Return on Investment) which could contribute to the increase of revenue of the government ensuring a lot of employments. In the year 2009-10 (February), there were 89 new foreign and joint venture investment projects registered to BOI which amountted to $\$ 590 \mathrm{~m}$. The projects were invested to mainly in the service, engineering, clothing and agricultural sectors which are shown through the following Chart:

Sectorwise foreign and joint venture investment during 2010-2011*

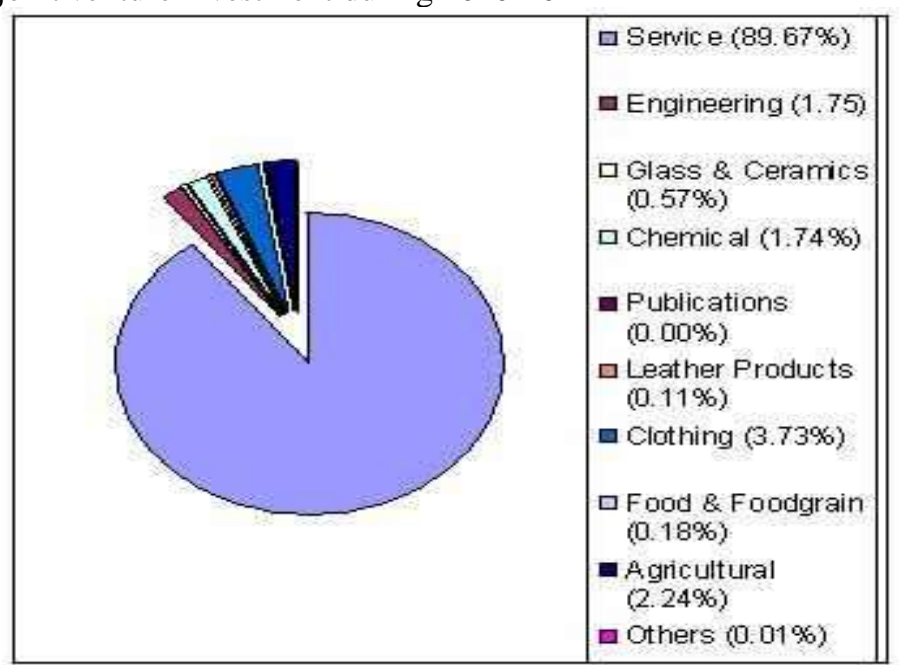

\section{* As of March, 2011}

Source:Bangladesh Economic Review-2011 (Bangla version), Ministry of Finance

From the above diagram it is seen that among the sectors concerned service sector belongs to the highest investment followed by clothing, agriculture, engineering and chemical sectors respectively.

Many countries are investing in Bangladesh and many ones are interested so far, but the scenario as a whole, is yet to be satisfactory. Despite that for the last four years many developed and developing countries invested in Bangladesh where USA stood first investing \$ 509.40 millions among the top 10 countries followed by UK (\$504.90 millions), Egypt (\$ 365.10 millions), UAE (\$. 309.70 millions), Hon Kong-China (\$.186.80 millions), Singapore (\$.173.00 millions), South Korea (\$.143.00 millions), Switzerland ( $\$ .84 .00$ millions), Netherlands (\$. 65.90 millions) and Pakistan (\$45.70 millions) respectively ${ }^{7}$.

For the last four financial years total FDI had been available in Bangladesh for \$ 3110.00 millions out of which a $\$ 2387.30$ millions was invested by the 10 countries mentioned above. Besides, many other countries of the world invested more for $\$ 7221.00$ millions in this country. The analytical scenario can be shown below (Vide Table 2):

In the Table, year to year comparison highlights that FDI in 2006 was less than that of in 2005, while it was increasing in 2007 and decreasing again in 2008 compared to 2007. Statistics reveal the facts that during 2005 the FDI was for $\$ 803.80$ millions and it declined to $\$ 744.70$ millions in 2006 . The little bit increase of the 
FDI stood at $\$ 792.80$ millions during 2007 compared to the previous year while it again decreased to $\$ 768.70$ millions during 2008-09.

Foreign Direct Investment (FDI) has played a key role in the modernization of the Bangladesh economy for the last 15 years. There was an inflow of $\$ 666 \mathrm{~m}$ foreign direct investment in 2007 which rose significantly in 2008 to $\$ 1086 \mathrm{~m}$. As of 2010 , inflows of foreign direct investment recorded to $\$ 971 \mathrm{~m}$ and these can be highlighted in the following Graph:

Inflows of foreign direct investment during 2005-2010

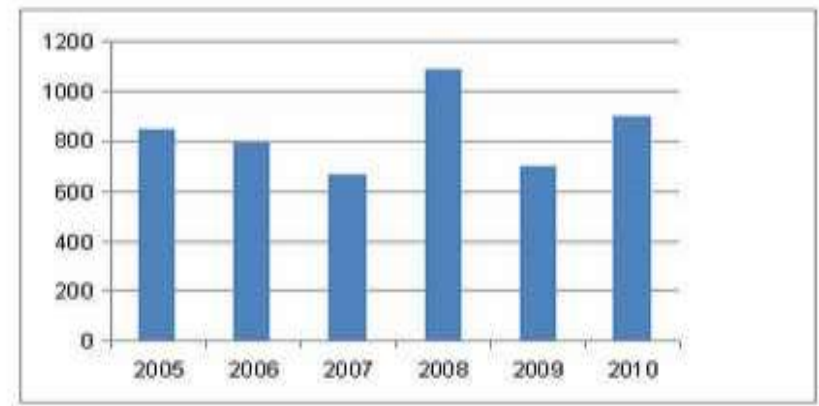

Source: World Investment Report 2011

More clearly, the countries which contributed in this regard can be highlighted here (Vide Table 3).

The statistics of the Table depict that the trend in FDI of USA, UK, Singapore and South Korea had been fluctuating, while the same of Egypt, UAE and Hong Kong-China had been increasing so far. For example, during 2005-06 the FDI of the former countries was \$ 105.90 millions, 153.50 millions, 97.50 millions and 26.30 millions respectively while the same had been 187.60 millions, 77.90 millions, 26.30 millions and 50.10 millions in 2006-07; \$ 161.50 millions, 123.70 millions, 11.80 millions and 30.00 millions in 2007-08, and during 2008-09 the FDIs were for $\$ 54.50$ millions, 189.80 millions, 37.30 millions and 36.60 millions respectively. The increasing trend in FDI of the later countries was seen as for $\$ 42.00$ millions, 12.80 millions and 26.30 millions respectively during 2005-06, and these were 67.40 millions, 105.00 millions and 43.30 millions in 2006; during 2007-08 the same had been 123.40 millions, 62.00 millions and 62.50 millions, while 132.30 millions, 134.20 millions and 41.60 millions were during 2008-09 for the same countries. Most of the FDIs of USA are invested in Bangladesh for gas sector. Of course, USA recently expressed its interests in investing for electricity and coal. Again, Egypt and UAE have the investments on mobile phone, hotel and tourism. Besides, Microsoft of USA, Dhabi Group of UAE, SingTel of Singapore, Orascom of Egypt and YKK of Japan have already invested in Bangladesh. Again, the proposed investment amount around \$100 million consisted of Toray Group of Japan, Kingdom Group of KSA, Tata Group of India, china, Malaysia, Taiwan and Australia is under the process of recommendation. Also in the very recent time Mittal Group of UK, Ecorntech of USA, Agility of Quiet and so on have expressed their deep concern over the investment in Bangladesh ${ }^{\mathbf{8}}$.

In fact, FDI includes three components in the context of Bangladesh, while Equity capital is the principal component (60 percent) of FDI which was in 2007 followed by reinvested earnings (32 percent) and intracompany loans (8 percent) so far. The idea could corroborate in detail during 2001-2007 (Vide Table 4).

The Table clearly shows the fluctuating trend of the inflow of FDI in Bangladesh during the period mentioned, which does not highlight the sound support in a sound economy.

Apart from the scenario mentioned above the Private Investment Statistics can also be shown for highlighting the position of FDI in Bangladesh (Vide Table 5).

In terms of the Private investment Statistics the growth rate of FDI had been fluctuating during the period 2005-06 to 2010-11 which does not reveal the congenial atmosphere and that corroborate the scenarios depicted above, though the private investment trend from the year 2009-10 to 2010-11 was somehow supposed to be increasing.

\section{Necessity of FDI in Bangladesh}

It is inevitable in the global perspective that FDI has a great impact on the country's economy, because country like Bangladesh generally faces capital problem regarding the implementation of capital projects which is much necessary for the alleviation of poverty through the industrial development as a whole. Actually, Bangladesh could be considered a better place compared to many other countries in terms of FDI. Because, Bangladesh is considered to be an attractive destination in South Asia for doing businesses. The recently published potential report by the World Bank and IFC has ranked Bangladesh 110th among 181 economies of 
the world in this regard. For example, rank of some selected countries for Ease of Doing Business is 1 for Singapore, 69 for Maldives, 77 Pakistan, 102 for Sri Lanka, 110 for Bangladesh, 121 for Nepal, 122 for India, 124 for Bhutan and 162 for Afghanistan. However, the rank of Bangladesh in 'investor protection' is 18, which is even better than many developed economies'. Hence, FDI could really play a crucial role in Bangladesh.

\section{Problems associated with FDI in Bangladesh}

Since the year 1980 the FDI has been playing role towards the economy of Bangladesh described earlier, yet it is to be propitiatory. Because, it is true that the quantity of FDI is less in Bangladesh than that of the other countries like Singapore, Thailand, Malaysia, India, Sri Lanka, South Korea etc. ${ }^{\mathbf{1 0}}$ Besides, the flow of FDI in Bangladesh as compared to the neighboring, regional and developed countries was not competitive during 1985-2003 (Vide Table 6) ${ }^{\mathbf{1 1}}$ :

The Table makes it clear that the distribution of FDI is unequal among the countries concerned. Of course, inequality does not mean that the place for FDI in Bangladesh is much suitable compared to the same of those countries concerned. Here in Bangladesh we have some limitations and these can be explained below:

Unsound Ratio between Saving-GDP and Investment- GDP: The gap which prevails between these two ratios is not congenial in the perspective Bangladesh economy (Vide Table 7) ${ }^{\mathbf{1 2}}$.

The Table signifies that there was a huge gap between the Investment and Savings in each of the financial years in case of Government Sector compared to the Non-Government Sector which led the total differences to be unsatisfactory.

Market Instability: Market rate is fluctuating here, which could not attract the FDIs, besides, the purchasing power of the people in Bangladesh is somehow low;

Natural Disasters: Geographically Bangladesh remains under the pressure of natural calamities when the investors become afraid of investing their money;

Political Instability: For the last couple of years it is clearly seen that unrest political situation depreciates the foreigners to invest their capital in Bangladesh;

Corruption: This term in Bangladesh resists the investors, while Bangladesh became the champion in corruption several times;

Bureaucratic Difficulties: While implementing FDI a lot of formalities have to be maintained through the official processes which take more time and the investors become hampered as well as annoyed;

Economic Indicators: Most of the indicators like GDP,GNP, Per Capita Income, Growth Rate, Balance of Trade and Balance of Payments etc are not so attractive compared to the neighboring countries as well as other regional countries of the world. The sound share market could be a good atmosphere for the development of economic growth, where as no FDI is in a touch of the said market so far;

Power Generation: Insufficiency of Power generation along with gas, fuel and water supply is a common picture in the context of Bangladesh which does not attract the investors so far;

Public Private Partnership (PPP): This would be a great achievement if a country can introduce it properly, because in the age of globalization it is considered to be an effective project. In this country the same cannot take place according to the present needs;

Besides those problems mentioned above, inefficient labor, poor infra-structural condition, lack of joint effort, in-cooperation of local investors, suspicious sentiments, regional and international politics are considered to be the hindrances in getting the sound FDI in Bangladesh.

\section{Conclusion and Suggestions}

From the analysis and discussion, it is observed that the FDI has been playing its role to the economy of Bangladesh since long, but whether the role is fruitful or productive can be a questionable phenomenon because of the fluctuating trend of the same. Again, the quantity of FDI is less than that of the neighboring as well as regional countries. The flow of FDI here is not so satisfactory compared to the other countries concerned as well. Besides, the attractive project, PPP is yet to be developed. Though the present Government has taken initiative to implement the same and the Budget 2009-10 and 20010-11 will provide the fund in this regard, the status of the same as a whole is not commendable. On 19.11.2009 it was seen in The Bangladesh Observer that a PPP regarding 'Dhaka Elevated Express Way' had been circulated as international tender but in fact, the quantity of the projects has to be increased more for FDI. Actually, before passing the clear-cut opinion or comments regarding the impact of FDI many relevant factors have to be considered in this regard. However, to increase as well as expedite the FDI strength in Bangladesh some steps could be taken so far and these are:

a) Reduction of the gap between Saving-GDP ratio and Investment-GDP ratio: Insignificant gap between these two ratios has to be created through increasing savings and investments so that both the ratios could contribute towards the economy of Bangladesh by playing role for increasing GDP;

b) Corruption free society: To attract the FDI corruption free society must be ensured so that foreign investors could invest without facing any hesitation; 
c) Development of Economic Indicators: The said indicators have to be increased by controlling costs, generating incomes through maintaining proper Accounting System;

d) Transparency and Accountability: These two crucial terms have to be established in every sector of the country so that hampers or clumsiness could be removed;

e) Political stability: Peaceful atmosphere has to be established through the help as well as cooperation of both the Government and Oppositions;

f) Development of Infra-structural Conditions: It is true that our infra-structural condition is not strong enough; hence the said development is a must;

g) Development of Relationship with the International Organizations: For the third world countries WTO plays a crucial role, where the rights of the developing countries have to be properly preserved through the strong lobbing. Because it is recently seen that among the developing countries India, Brazil, South Korea and some other countries are playing potential roles for seeking their own interests in the WTO conferences which is considered to be a bad signal for us, because that could hamper our export earnings especially in case of garment sectors. Hence the very relationship has to be developed through the pragmatic diplomatic efforts;

h) Measures for Controlling Natural Disasters: It is fact that we have no hand on the disasters, but Government could take some positive steps like developed forecasting system, better shelter places, adequate food stock, online communication with the donor countries and agencies, direct communication with the local rich people etc based upon which the investors could be motivated;

i) Exploration of Gas, Fuel and Generation of Electricity: Until and unless the investors become sure regarding the satisfactory position of the said determinants, they would not be interested so far. In this regard the concerned companies like Unicol, Sheltech, Asia Energy and other sound companies have to be convinced through taking proper steps for the development of the said important factors.

j) Tax Holiday and Tax Rebate: Facilities regarding these sides should be confirmed so that the investors could be attracted so far;

k) Clearance on transferring foreign money from Bangladesh Bank: Obstacles of transferring money to abroad have to be relaxed. Because, the foreigners have to take permission from the said bank in terms of transferring profit/commission earned by them in this country. Of course, the Bangladesh Bank has some how relaxed the bar and in this regard FDI would be upgraded.

Furthermore, holding national and international fairs, improvement of law and order situation, proper distribution of wealth, development of public private partnership (PPP), immediate decision for investment projects, increasing foreign reserve (presently foreign exchange reserve has gone up to 11 billions so far at the end of the $3^{\text {rd }}$ quarter of the year 2012-Statistics department of Bangladesh Bank), development of the efficiency of labors etc have to be confirmed in this regard.

[1] Bangladesh Bank, Annual Report, 2006-07, pp.4-5.

[2] Opcit

[3] K. M.A. Rahman, Globalization and the Climate of Foreign Direct Investment: A Case for Bangladesh, Journal of Money, Investment and Banking ISSN 1450-288X Issue 5 @, Euro Journals Publishing, Inc. 2008.

[4] M. Anu, Foreign Direct Investment and Utilization of Natural Gas in Bangladesh: A note on understanding the trap in Development Disguise, www.FDI in Bangladesh.com .

[5] FDI in South Asia: 'Challenges and Prospects', South Asia Watch on Trade, Economics \& Environment (Briefing Paper), No.1, 2003, p.1.

[6] Ibid

[7] The daily Samakal, 01.08.2009, p. 14

[8] M. Ali and N. Alam, The Economy of Bangladesh, ( Ideal Library, Dhaka, $8^{\text {th }}$ Edition, 2008).

[9] The World Bank and IFC, Doing Business-2009.

[10] M.Ali and N.Alam, Opcit

[11] Khan Md.Azizur Rahman, Opcit

[12] Bangladesh Bank ,Opcit

\begin{tabular}{|c|c|c|c|}
\hline \multicolumn{4}{|c|}{$\begin{array}{c}\text { Appendix-1 } \\
\text { List of the Tables } \\
\text { Table-1 } \\
\text { Country wise FDI position during 2006- } 0\end{array}$} \\
\hline Region and Country & Projects & Millions(TK.) & Registered with BOI \\
\hline Asia-13 countries & 88 & 889930.80 & in Bangladesh \\
\hline Europe- 12 countries & 30 & 42321.20 & in Bangladesh \\
\hline America & 12 & 5026.00 & in Bangladesh \\
\hline Canada & 03 & 469.80 & in Bangladesh \\
\hline
\end{tabular}

Note: BOI-Board of Investment.

Source: M.Ali and N. Alam, The Economy of Bangladesh, Dhaka: Ideal Library, p.433. 
Table-2

Year wise FDI in Bangladesh

$\begin{array}{lllll}\text { Foreign Direct } & 2005-06 & 2006-07 & 2007-08 & 2008-09 \\ \text { Investment } & 803.80 & 744.70 & 792.80 & 768.70\end{array}$

(\$ in Millions)

Source: The Daily Samakal, 01.08.2009.

Table-3

Country wise contribution to FDI in Bangladesh

$\begin{array}{lllll}\begin{array}{l}\text { Foreign Direct } \\ \text { Investment } \\ \text { (\$ in Millions) }\end{array} & 2005-06 & 2006-07 & 2007-08 & 2008-09 \\ \text { USA } & 105.90 & 187.60 & 161.50 & \\ \text { UK } & 153.50 & 77.90 & 123.70 & 54.50 \\ \text { Egypt } & 42.00 & 67.40 & 123.40 & 189.80 \\ \text { UAE } & 12.80 & 105.00 & 62.00 & 132.30 \\ \text { Honk Kong-China } & 26.30 & 43.30 & 62.50 & 134.20 \\ \text { Singapore } & 97.50 & 26.30 & 11.80 & 41.60 \\ \text { South Korea } & 26.30 & 50.10 & 30.00 & 37.30 \\ & & & & 36.60\end{array}$

Source: The Daily Samakal, 01.08.2009.

Table 4

FDI Inflow in Bangladesh during 2001-2007: Distribution by Components

(In Million US\$)

$\begin{array}{lccccccr}\text { FDI } & 2001 & 2002 & 2003 & 2004 & 2005 & 2006 & 2007 * \\ \begin{array}{l}\text { components } \\ \text { Equity }\end{array} & 233.8 & 133.8 & 156.1 & 155.9 & 425.6 & 503.7 & 401.6 \\ \begin{array}{l}\text { Capital } \\ \text { Reinvested }\end{array} & 65.0 & 116.8 & 170.2 & 239.8 & 247.5 & 264.7 & 213.2 \\ \begin{array}{l}\text { Earnings } \\ \text { Intra } \\ \text { company }\end{array} & 55.7 & 77.7 & 24.0 & 64.7 & 172.2 & 24.1 & 51.5 \\ \begin{array}{l}\text { Loans } \\ \text { Total FDI }\end{array} & 354.5 & 328.3 & 350.3 & 460.4 & 845.3 & 792.5 & 666.3\end{array}$

* Provisional

Source: Enterprise Survey, Bangladesh Bank

Table 5

Private Investment Statistics

\begin{tabular}{|l|l|c|l|l|l|c|r|}
\hline Year & \multicolumn{2}{l|}{$\begin{array}{l}\text { Proposed Local } \\
\text { Investment }\end{array}$} & \multicolumn{2}{l|}{$\begin{array}{l}\text { Proposed } \\
\text { Foreign } \\
\text { Investment }\end{array}$} & \multicolumn{2}{l|}{$\begin{array}{l}\text { Total Proposed } \\
\text { Investment }\end{array}$} & \multicolumn{2}{l}{$\begin{array}{l}\text { Growth } \\
\%\end{array}$} \\
\cline { 2 - 7 } & Project & BDT & Project & BDT & Project & BDT & \\
\hline $2005-2006$ & 1754 & 18370 & 135 & 24986 & 1889 & 43356 & 124.62 \\
\hline $2006-2007$ & 1930 & 19658 & 191 & 11925 & 2121 & 31583 & -27.15 \\
\hline $2007-2008$ & 1615 & 19553 & 143 & 5433 & 1758 & 24986 & -20.89 \\
\hline $2008-2009$ & 1336 & 17117 & 132 & 14749 & 1468 & 31867 & 27.54 \\
\hline $2009-2010$ & 1470 & 27414 & 160 & 6261 & 1630 & 33678 & 5.67 \\
\hline $\begin{array}{l}2010- \\
2011 *\end{array}$ & 1298 & 39976 & 148 & 26935 & 1446 & 66912 & 98.71 \\
\hline
\end{tabular}

* March, 2011

Source:Bangladesh Economic Review-2011 (Bangla version), Ministry of Finance 


\begin{tabular}{|c|c|c|c|c|c|c|}
\hline \multirow[b]{2}{*}{$\begin{array}{l}\text { Country } \\
\text { Bangladesh }\end{array}$} & \multicolumn{6}{|c|}{$\begin{array}{c}\text { Table } 6 \\
\begin{array}{c}\text { FDI flows in Various Countries } \\
\text { (Million of Dollars) }\end{array}\end{array}$} \\
\hline & $1985-95$ & 1999 & 2000 & 2001 & 2002 & 2003 \\
\hline $\begin{array}{l}\text { Inward } \\
\text { India }\end{array}$ & 3 & 180 & 280 & 79 & 52 & 121 \\
\hline $\begin{array}{l}\text { Inward } \\
\text { Myanmar }\end{array}$ & 455 & 2168 & 2319 & 3403 & 3449 & 4269 \\
\hline $\begin{array}{l}\text { Inward } \\
\text { South, East } \\
\text { and South }\end{array}$ & 110 & 304 & 206 & 192 & 197 & 128 \\
\hline $\begin{array}{l}\text { East Asia } \\
\text { Inward } \\
\text { Developing } \\
\text { Economics }\end{array}$ & 30189 & 109115 & 142683 & 102728 & 86342 & 96915 \\
\hline $\begin{array}{l}\text { Inward } \\
\text { World }\end{array}$ & 50779 & 231880 & 254249 & 219721 & 157612 & 172033 \\
\hline Inward & 181704 & 1086750 & 1387953 & 817514 & 678751 & 559576 \\
\hline
\end{tabular}

Source: UNCTAD, World Development Report 2004.

Table 7

Internal Savings and Investments

(As Percentage of GDP)

Particulars

\begin{tabular}{llll}
\multirow{2}{*}{ Government } & \multicolumn{2}{c}{2004} & \multicolumn{2}{c}{2005} \\
& Investments & 6.20 & 6.20 \\
Non- & Savings & 1.30 & 1.40 \\
Government & Differences & -4.90 & -4.80 \\
\multirow{4}{*}{ Total } & Investments & 17.80 & 18.30 \\
& Savings & 18.20 & 18.60 \\
& Differences & 0.40 & 0.30 \\
& Investments & 24.00 & 24.50 \\
& Savings & 19.50 & 20.00 \\
& Differences & -4.50 & -4.50
\end{tabular}

$\begin{array}{ll}\begin{array}{ll}\text { Financial year } \\ 2006\end{array} & \begin{array}{l}\text { Financial year } \\ 2007^{*}\end{array} \\ 6.00 & 5.60 \\ 1.40 & 1.40 \\ -4.60 & -4.20 \\ 18.70 & 18.70 \\ 18.80 & 19.00 \\ 0.10 & 0.30 \\ 24.70 & 24.30 \\ 20.20 & 20.40 \\ -4.50 & -3.90\end{array}$

Source: National Accounts Statistics, June 2007. Bangladesh Bureau of Statistics.

- Provisional.

\section{References}

[1] M Ali and N.Alam, The Economy of Bangladesh (Dhaka: Ideal Library, $8^{\text {th }}$ Edition, 2008).

[2] J.Abedin, Bangladesh: Share O Punji Bazar (Dhaka: Antarip Publication, $2^{\text {nd }}$ Edition, 2008).

[3] Bangladesh Bank, Annual Report,2007.

[4] -------------------, Enterprise Survey, 2007

[5] ---------- Monthly Economic Trend, Bangladesh Bank, Statistic

i. Department, Vol.XXXIII No. 8

[6] Bangladesh Garment Manufacturers and Exporters Association, Annual Report, 2007.

[7] J,W. Best and J.V. Kahn, Research in Education ( New Delhi, Prentic-Hall of India Private Ltd, $5^{\text {th }}$ Edition).

[8] A,R .Bhuyan, An Overview of the Bangladesh Economy: Recent Performance and Future Challenges in hought on Economics, Vol.7 No. 3 \& 4.

[9] FDI in South Asia (2003), Challenges and Prospects, Briefing Paper in South Asia Watch on Trade, Economics \& Environment, No.1.

[10] Institute of Chartered Accountants of Bangladesh, The Bangladesh Accountant', Vol. 35, No. 8, 2002.

[11] M,A,R .Khan, Globalization and the Climate of Foreign Direct Investment: A Case for Bangladesh, Journal of Money, Investment and Banking, ISSN 1450-288X Issue, 5 @ Euro Journals Publishing, Inc. 2008.

[12] Ministry of Commerce, Export Policy, Govt. Of Bangladesh (GOB), 2006-09.

[13] Ministry of Commerce, Import Policy Order, GOB, 2006-09._____ Annual Budget, Budget in Brief, GOB, 2008-09.

[14] Ministry of Finance, Bangladesh Economic Review, GOB, .Ministry of Industry, SME Sector Development Programm, GOB, 2007 and 2008 .

[15] The Bangladesh Observer, International Notice for Investors Prequalification for Dhaka Elevated Express Way on Public-Private Partnership (PPP) Basis, 2009.

[16] The daily Samakal, Char Basare Bangladesha Binioga Shirshe Juktorastra, 2009.

[17] The Relevant Web Sites Data.

[18] The World Bank and IFC, Doing Business, 2009. 